\title{
Canadian Society for Renaissance Studies Report on Annual General Meeting, 2 June 1982, Ottawa
}

\section{Report of the Secretary-Treasurer}

$\mathrm{K}$. Bartlett reported that the CFH Administrative Grant had been received and this will cover the costs of the Executive Meeting held in Toronto in February, as well as the costs of mailing, supplies, typing and similar charges. The CFH travel grant was less than usual this year because the formula provides funds for members to travel to their Society based on a number of variables, one of which is regional distribution and distance from the location of the meeting. Since most of our membership is concentrated in Ontario and Québec, our grant was proportionally smaller.

The total membership has declined marginally since last year, largely as a result of the general economic climate. Also, our regional and disciplinary representation is unbalanced. It is hoped that this uneven distribution might be improved.

\section{Editor's Report}

R. Van Fossen was unable to attend but sent his report which was read by K. Bartlett:

"The situation with the journal is rather different from what it was last year. We have what we think are 560 real subscriptions, 310 paid up as of May 28 in comparison with 289 at this time last year. Our mail campaign has brought in a fair number of new subscriptions, many of them from libraries in Great Britain, Europe, and the United States. Several insitutions have ordered complete back files.

"The SSHRC received glowing appraisals from its three external referees, with the result that the Council awarded us a grant for 1982 above the formula. We are in relatively healthy shape financially (though we always need more subscribers). Each of this year's issues will contain 80 pages instead of last year's 64 .

"Unfortunately, we are far behind in our publication schedule. The postal strike last summer was ruinous, and a series of unfortunate events has delayed things further: the most recent catastrophe is that the press ran out of our text paper; delivery is expected this week, and we hope that the February issue will be mailed on June 9. The May and August issues will also be delayed, but we hope to be back on schedule for November."

The managing editor of Renaissance and Reformation/Renaissance et Réforme, Glenn Loney, added that materials submitted to the journal should carry first-class postage stickers and the address should appear in the same place as on a letter-sized envelope. Contributors were requested to keep the editor informed of changes of addresses, including temporary or summer accommodations. This will facilitate the mailing of proofs. 


\section{President's Report}

E. Limbrick conveyed an appeal from IRIS for support. This valuable resource for Renaissance scholars requests $\$ 7$ from each reader to be sent to Professor R. Ortali, SUNY. Anyone not yet receiving IRIS should similarly contact Professor Ortali.

The Board of Directors of the CFH is at present concerned with issues affecting the humanities and the federal and provincial funding of universities. Professor Limbrick sits on this Board and is involved with these issues and in particular with the dangerous proposal for increasing strategic grants at the expense of free research. Lobbying of M.P.s will take place during the Learneds and it is suggested that each interested member write his or her M.P. as well.

\section{Nominating Commitee, 1982-84}

The report of the Nominating Committee was presented. The Committee, consisting of Professors Limbrick, De Bujanda and Sutto, submitted the following to the membership, noting that the requirements for regional and disciplinary representation have been met: President, 1982-4: K.R. Bartlett; Vice-President: R. Melançon; Secretary-Treasurer: W.H. Herendeen. The seven members of the Council are: M. Best (Western Canada); M. Bergbusch (Prairies); D. Beecher (Ontario); A. Berthiaume (Québec); G. Allaire (Maritimes); G. Hobbs (Theology); M. Ciavolella (Italian). H. Secor, seconded by F. Paré, moved that nominations be closed. F. Paré, seconded by E. Limbrick, moved acceptance. Carried unanimously.

\section{Programme}

E. Limbrick will serve as programme chairman for the 1983 meeting in Vancouver; the local representative will be A. MacKay. Suggestions for the programme were requested including ideas for theme(s) and invited speakers. It was suggested that the call for papers has been too late and that the first call should be issued early in the Fall. Reports of regional activities and important matters in several disciplines should be made available in the programme. One joint meeting with another society was seen as useful but we must watch diluting our focus overmuch. The danger to an interdisciplinary society such as the CSRS/SCER from a lack of cohesion and identity was noted.

A member suggested that themes be chosen for our meetings that would attract new members from under-represented disciplines. Also, communications on research and work-in-progress were seen as valuable, despite the organizational problems involved. Perhaps small working groups might be formed as seminar discussions; and the forth-coming Directory can be used effectively to improve communications. Each member should go forth and recruit new members.

\section{Other Business}

A. Raspa has volunteered to edit a CSRS/SCER Newsletter. About three single sheet numbers will appear each year recording and promoting work and events of interest to the Society. The success of the Newsletter will depend on the material submitted by the membership, so all members are encouraged to send anything of interest to 
Professor A. Raspa, Département des langues modernes, Université du Québec à Chicoutimi, 555 Chemin Saint-Thomas, Chicoutimi, Québec, G7H 2P9. (Tel. [418] - 545-5276.)

D. Beecher reported that he has been chosen the North American editor of Cahiers Elizabéthains and he is requesting articles dealing with the period 1500-1660, especially those in English studies. He also encourages individual (\$22/year) and library subscriptions. In addition, Professor Beecher drew the Society's attention to the Carleton Renaissance Plays in Translation series, of which four titles are now in print and four or five others in progress. Further proposals are welcome.

M. Bareau distributed a flyer from the Alta Press/les Editions Alta. The editors request manuscripts for consideration, particularly those in the area of neo-latin literature, critical editions and studies in French and Spanish 16th and 17th Century literature. The address is Box 391, Sub-11, University of Alberta, Edmonton, Alta., T6G 2E0.

K. Eisenbichler, Curator of the Centre for Reformation and Renaissance Studies, reminded the Society that the rare books in the CRRS Library are not all catalogued in the University of Toronto Union Catalogue. A series of CRRS Catatlogues have been published and he suggests that interested libraries order the three catalogues now in print (classics, histories, Bibles and theological works).

Also, CRRS has begun a project to publish Renaissance works in translation for the use at the undergraduate level. Proposals will be gratefully received. Finally, CRRS has a non-stipendary Senior Fellowship Programme that provides study space in the Centre, library access, and membership in the Senior Common Room of Victoria College for scholars wishing to spend their leaves in Toronto.

$\mathrm{K}$. Bartlett reported that Ms Audrey Forster of SSHRC has requested nominations of members of the Society to be added to the data bank of names suitable for the Council's Academic Panels and Committees. Interested members should forward their C.V.s to Ms Audrey Forster, Secretary, SSHRC, 255 Albert Street, P.O. Box 1610, Ottawa K1P 6G4. 